\title{
Atheism and Humanism in a Globalized World: The Igbo Experience
}

\author{
Chizaram Onyekwere, Oliver Uche \\ Department of Religion and Human Relations, Faculty of Arts, Nnamdi Azikiwe University, Awka, Nigeria \\ Email: ucheooc@yahoo.com
}

Received January $10^{\text {th }}, 2013$; revised February $13^{\text {th }}, 2013$; accepted February $22^{\text {nd }}, 2013$

\begin{abstract}
Obnoxious labels are derogatory terms which speak extensively on the ignorant dispositions of scholars who either rush into faulty conclusions, or have prior decisions to promote class distinction through the uncomplimentary colours they paint of what others hold as divine, spiritual, and transcendental. For such derogatory terms to gain wide audience in a globalized age explains the frame of mind of discordant voices which have been based on arm-chair scholarship. The thrust of this article therefore, is to use Igbo experience to explore the problems of atheism and humanism in a globalized world. The exploratory research will help adopt a cultural centred approach in analyzing the dichotomy between the various philosophical view points on God, spirits and man's religious belief system in Igbo land in particular and Africa in general. It is hoped that the analyses of the challenges posed by atheism and humanism in a globalized world will balance ideas, views, attitudes and behaviour that will reposition Igbo religious beliefs, values and practices in line with the proposed theistic humanism associated with Igbo culture in particular and African culture in general. This will breach the persisted conflict between the sacred and the secular pointing to a dynamic and progressive Igbo culture.
\end{abstract}

Keywords: Atheism; Humanism; Globalised World; Igbo; Igbo Experience

\section{Introduction}

The need to distillate a balanced view that is fundamental enough for the renewal of social life in a globalized world has been very high. Accepting an invitation to contribute to Maduabuchi Dukor's "four great works on African Philosophy" constitutes a fresh challenge. There is a need to use Igbo experience to explore fresh and improved insight to atheism from humanism in a globalized world. This has become necessary because of lots of misconceptions, ignorance, arm-chair scholarship, and derogatory labels promoting class distinctions between Africa and the rest of the world. Similarly, there are discordant voices on types and relationships between atheism, humanism, secularism, agnosticism, theism an theistic humanism. Despite the diverse relationships in the above types of concepts of God, humanism has Christian, secular, philosophical, scientific and theistic humanism. The danger in the above classification of the above major intellectual modifications of humanism is their views about the supernatural aspects of man. However, these scholarly view points seem to have found unity in temporal welfare, dignity and equality of all men.

Atheism and humanism are not the same. They have different cultural background and as they are used and applied to different philosophies, their philosophical movements differ over time situations and institutions. Why must people, especially in the western world refuse to acknowledge or profess any of the world main religions? Mairi (1998) defines atheism as the belief that there is no god. He did not seem to distinguish between god and God. Could they mean the same thing? What is described as god is not so described by the Igbo, rather, they call them divinities or messengers in the theocratic government of God. The critique and denial of belief in God have raised a number of variables such as beliefs, rejection of the idea of God, spirit or life force altogether.

Opinion on atheism remains a subject to different interpretations. It indicates a strong decline in religious belief. Consequent upon different interpretations, Haralambos, Holborn and Heald (2008) say "they could be seen as providing on whether a narrow or broad definition of religion is employed" (p. 434). Humanism on the other hand goes beyond a cultural movement of the classical period which promoted classical studies.

\section{Conceptual Clarification}

A number of concepts deserve a touch of explanation of their meaning in the light of this paper. Notable among these themes are atheism, humanism, globalized world and Igboland. Others are by implication order, ethical life and experience. The insight offered by these terms will offer a deeper understanding of the discussion of the Igbo experience of atheism and humanism in a globalized world.

\section{Atheism}

Doniger (1999) says atheism refers to "the critique and denial of belief in God, as such, it is the opposite of theism, which affirms the reality of God and seeks to demonstrate his existence" (p. 87). Atheism is associated with a number of variables such as beliefs, rejection of the idea of a God, spirit or life force altogether.

Atheism indicates a strong decline in religious belief. Opinion on atheism has been a subject to different interpretations. Consequently, Haralambos, Holborn and Heald (2008) say "they could be seen as providing on whether a narrow or broad 
definition of religion is employed” (p. 434). Hamilton (1998) says that one to say he believes in God:

Does not mean that it has any consequence for behaviour, is held with any conviction, or has any real meaning. What is surveys show is not that people are religious but that they have a propensity to say yes to this sort of survey questions.

\section{Humanism}

Humanism goes beyond a cultural movement of the classical period which promoted classical study. This concept refers to a body of philosophies and ethical perspectives that emphasize the value of human beings, individually, collectively, and generally place more importance on rational thought than on strict faith or adherence to principle.

It could mean non-religious beliefs in philosophy and social science. Humanism refers to a perspective that affirms some notion of a human nature. Humanism describes the secular ideology that espouses reason, ethics and justice, while specifically rejecting supernatural and religious ideas as a basis of morality and decision making. Esptein (2010) states that "Humanism today can be categorized as a movement, a philosophy of life or world view, or life stance” (p. 169).

Mairi (1998) feels that humanism refers to "a system of thought which rejects the supernatural, any belief in a god etc., but holds human interest and the human mind paramount; that humans are capable of solving the problems of the world and deciding what is or is not correct moral behaviour" (p. 655). The implication of the rejection of the supernatural does not remove the different aspects of the human being such as being spiritual, moral

\section{Globalized World}

Globalized world in this paper is articulated as the various ways and means the universe is made a village through the instrumentality of Information Communication Technology (ICT).

\section{Igbo Land}

Igbo land will refer to a geographical expression of the south eastern states and some parts of Rivers, Delta, Akwa Ibom, Benue and Kogi States in Nigeria.

\section{Atheism: An Academic Engagement}

Belief system illustrates the tendency to which man irrespective of creed, philosophies of life, status and world views, is predisposed to religious philosophy. Atheism is a norm, a mark, disbelief, opposition, non-existence, prejudice and denial or non-acknowledgement of God which is the object of worship in religion. The inability to portray any of the world main religions could be as a result of holding God responsible for the ills of the world. Man is not seen as a corruption of good, corrupt and wicked.

It is not impossible that people identify with atheism. They, on moral or intellectual grounds, find that they cannot believe in God. They are those Idowu (1978) describes as "for some inexplicable reason, are just in capable of believing” (p. 28). Atheists are one of the four categories or thinkers that have attacked or criticized religion. However, he sees atheist as the same as secularists. It is difficult to accept the groups as the same or referring to those who are reacting against religion in consequence of priest craft and the abuses and evils promoted or perpetrated in connection with religion.

Such disbelief could not affect God's nature or deity. However, atheists have no demonstrable existence of God and they could not find functional occasion to bring God into the practical business of everyday life. Could it be established that the material world which is visible, tangible and dynamic holds such reality that had to do with life in general or with themselves in their existential situations.

It is evident that the universe in which man finds himself does not seem to make sense. Thus, man's powers at best are limited and cannot avoid making sense of it. For a steady development of purpose, gradual unfolding of plans is necessary. Man's conquest of nature is to a great extent achieved by a wise submission, as a clever wrestler uses jujitsu. It is only the survivors in the evolutionary process that display such abilities. MacGregor states that "man, however, is in everywhere conspicuously advanced in such mortals. Yet the abilities he posses cannot be said to have grown. On the contrary, they have created in a process in which only those in whom such abilities were developed could survive. All these seem to suggest a creative mind rest mind to undertake and accomplish such purposes” (p. 92).

Is there anything that can be called good without qualification? It is evident also that nothing is good without qualification, but the image may be and is sadly distorted. Nothing is good except God. I can be what is intrinsically good, namely, what God intended me to be.

\section{Humanism in a Globalized World}

Humanism is from the Latin noun humanus understood as human or belonging to Homo sapiens which explains the attitude of the human mind, which attaches importance to man and his faculties mundane state of affairs temporal aspirations and well-being. Dukor (2010) sees humanism as "a way of life, to give meaning to life and to find an outstanding of our place in society and, indeed, the universe: Humanism stands for the open mind in the open society" (p. 71). Humanism is very current in philosophical field and this probably explains why various thinkers have used it in different view points. Thus, humanism remains any system which puts human interest utmost. However, human interest in this context means different things to different people. Consequent upon this, Dukor (2010) maintains that it is suspicious to assert that whatever is human must necessarily be opposed to what is called divine or supernatural. The same suspicion could be raised concerning holding that humanism describes philosophies and those streams of thought which Onwuanibe avers that they are aimed at fostering the full development of man and protecting his dignity, loving and caring for him. The conditions that gave room for humanism may be different. However, man is central as an adherent of religion, whose commitment, to religious belief and practices stands him out in the ascribed little reference to God as a hallmark of humanism.

Humanism in a globalized world has notable features such as having intrinsic anthropocentricism. It remains a project in which man is the supreme question for man. Edward (1989) says humanism is any outlook or the way of life centred on human need and interest such as human means for comprehending reality, regarding human values as making sense only 
in the context of human life rather than in the promise of a suppose after death. Humanism is a philosophy for those in love with life.

On the other hand, humanism says nothing about the very innate nature of man, rather its philosophical and literary movements colour its outlook and as a way of life, it constitutes one of the factors of modern cultures. Humanism is characteristic in exposing some of the clearly secular stance (as antithetical to religion and transcendental realities that many humanists have come to assume).

Humanism presents a posture of the misguided as a protest against religion, transcendental realities and ontology. The advocates of humanism are viewed always as atheistic or a theistic, or agonistic secular or apotheosists i.e. equating man with God. Richard (1983) says humanism "focuses on the unmitigated potentialities and achievement of man, especially as manifest in the classical era led them to seek revival of the educational model of this era” (p. 1).

Dukor (2010) explains the ambiguity among scholars who have either written on humanism but it also extends to thought and the belief of many others who had faith in humanism without being conscious of the word humanism to designate their belief. The influence from ancient Greek philosophy to contemporary view point created room for discordant voices. Man is unique in religion, revelation and in humanism. Man is the centre point and ends in man. The reference point is not God but the material. Dukor (2010) explains that "humanists have consistently used scientific advances to justify their claims because scientific discoveries explain more and more about the natural world. So living less and less for supernatural explanations to get away with (p. 68). This man-centered philosophy has been queried for not recognizing God as transcending the universe, God's immanence, created order and nearness to man than life itself. It is a philosophical fact that God expresses Himself in values that are discoverable by man in experience. In a globalized world, with different philosophies of life, ideologies and systems, God is at least personal and at least conscious mind and he is both beyond the universe and immanent in it. The inability to accept this reality explains the rigidity of the humanists especially of scientific class to other forms of humanism such as Christian humanism and African humanism.

Humanism according to Umezinwa (2009) recognizes and venerates the existence and powers of humans. It's extreme form goes without a consideration for the supernatural. As a consequence, the idea of a creator God and the spirit of man are not considered real. On the other hand, if God exists, He is too weak to make impact on man and society in a globalized world.

Humanism is understood to stand for any man-centred philosophy. According to Abbaganno (1967), it is thus:

Humanism is any philosophy which recognizes the value or dignity of man and makes him the measure of all things or somehow takes human nature, its limits, or its interests as its theme (pp. 66-67).

This above view may not have recognized that the value and dignity of man may be enhanced or promoted through divine mandate. It could therefore, be observed that the view of any philosophy could be misleading since there are different versions of humanism. Philosophical, theistic, religious, Christian and scientific humanism do not mean the same but may according to Edward (1989) have "any outlook or way of life centred on human need and interest” (p. 1). Okoye (2007) says in fact, the vast gamut of philosophers and philosophies that have been identified with humanism lack homogeneity of understanding of the concept ... However, at the epicenter of Humanism is an intrinsic anthropocentrism. Mondin (1985) states that humanism is "project" in which "man is the supreme question of man" (p. 1). Human values are implied as making sense only in the context of human life, dignity and human person as its raison d'etre with a view towards understanding man in order to enhance and better the situation as well as protect his God given dignity.

\section{The Igbo Experience}

The challenges of global times will be understood when we gain insight into Igbo experience of the globalized world. This has become necessary in view of the dichotomy between the east and the west on certain cultural issues. The way the Igbo perceive their world according to Metuh (1987) is the complex of their beliefs and attitudes concerning the nature, structure and interaction of the being in the universe with particular reference to man. The said complex is further referred to as the people's teogony and cosmogony which invariably is condensed in their belief in the Deity and in stories and myths about the origin and development of the universe.

The scope of Igbo world view includes the Creator, all created things, divinities, spirits and ancestors. A clear perception of Igbo philosophy of life according to Kalu (1978) is made when Igbo communities vary assiduously preserve Igbo myths of origin as an explanation of why things are the way they are. The Igbo myths go a long way in expressing the Supreme Being in different names and attributes such as Chineke (Creator), Chukwu (Supreme God), Obasi (God), Obinigwe (Heavenly father), Olisaebuluwa (Ruler of the earth). These names of God and their attributes such as the controller of the universe, King, Judge, sustainer among others are as old as Igbo as a people and a nation. The same applies to other ethnic extractions in Africa.

Momoh (1996) is weakened by African Traditional Religious structure which has a broad based structure on belief in God, ancestors, spirits and magic. God is the creator is unique as the ruler, king, controller, judge and sustainer of the universe. It may not be true having Godlessness in ancient African metaphysics as portrayed by Momoh. Similarly, the abode of God in Africa is not the same as what is termed "god". There is a great difference between God and "god" in metaphysical structure of African world view. The abode of "god" is not locatable and cannot be destroyed. What is described as "god" is not so conceived by Africans in words of Uche (2009) they are messengers or ministers in the theocratic government of God. Notable among them are Ala (earth goddess), Amadioha (thunder and lightening divinity) and Agwu (divinity for divination). They do not have their abode or dwell in the physical realm but theirs are spiritual. In what constitutes the psychology of religious worship, they have like other religions of mankind, a place of worship and sacrifice. They constitute things of the mind or of the spirit. When adherents feel they have outgrown belief in them, the removal of physical structures does not affect the psychological aspect of their existence.

Uche (2009) sees divinities in Igbo religious world view as one of the sources of traditional religious ethics. In a related case, Uche (2009) identifies divinities as enforcing the socioreligious significance of taboos in Igboland. The Igbo believe in social functions of religion. Uche (2006) extols the dynamics of 
religion as a matrix of culture. The articulation of Igbo religious beliefs, norms and values show functional role of Igbo religion in promoting what Uche (2011) calls sustainable development in Igboland in particular and Africa in general.

There is an integration of the physical existence with the spiritual sphere of life. The physical depends heavily on the spiritual for its well being. God, spirits and man interact for the sustainable development of the Igbo world. Man strives in obedience to the divine rules and regulations in order to attract divine favour and blessings from the spirit world. The ancestors also known as the living dead mirror the life of the Igbo families. They guide and direct the affairs of members of their families. They guard against incurring the wrath of God by discouraging their members from abominable acts.

The notion of life (Ndu) or existence in Igbo experience is meaningful in relation to God, spirit, universe and man. The heavy accent which the Igbo place on human life, its enhancement and continuity has according to Nwala (1985) been dubbed "heavily anthropocentric" (p. 144). Human life is therefore the prime value and everything is expected to serve its realization. This highest value is made manifest in their personal names such as Ndubuisi (Life is greater than wealth). Nduka (Life is greater), Ndukaku (Life is greater than wealth or riches), Nduamaka (Life is good). Madu (2004) supports the Nwala's view that the supremacy of life (Ndu) in both cosmological order and in daily life and activities of the people is reflected in dynamic quality of material and human existence.

Atheism is a misplaced label which does not hold based on Igbo religious experience. Ndu (Life) is the existence which takes various forms in material and spiritual existence. At death which is said to be the dissolution of the flesh, the spirit enters a separate existence maintaining the life of the individual in another sphere of existence.

It could be inferred from the above that life encompasses both material and spiritual existence. Existence is dynamic because the people's material and spiritual well-being are controlled by God. Anything that threatens the material and spiritual well being of the Igbo is feared by the people because this would diminish the dynamic quality of life. Onunwa (1990) identifies one of such unfriendly agents that threatens life in Igbo land as illness and death. They do not occur by accident in traditional Igbo society which Uchendu (1965) says is divided into two namely, the visible (uwa) and the invisible (Ala mmuo). These two worlds overlap. The invisible world is made up of the Eligwe and Ala-mmuo while the visible Ala madu are inhabited by beings. Ejizu (1986) notes that Eligwe (the sky above) is the abode of Supreme Being (Chineke) and such major divinities like Amadioha (thunder divinity) and Anyanwu (light divinity). The earth is the home of the earth goddess, minor divinities, nature deities and man. The ancestors, and spirit-forces (good and evil) are believed to inhabit the underworld.

The import of the above classification of Igbo cosmological order is to establish a strong relationship between the physical or material Igbo world and the spiritual or invisible world of reality. They are inseparable in promoting the prime value which ensures its realization. This is achieved by introducing measure aimed at putting rebellious proned man in check. They include Igba-ndu (covenant), Idu-isi (oath taking), Isa-aka (plea of innocence), inu-iyi (swearing or taking an oath). Meaningful life or existence (Ezi-ndu) remains an inter-play and integrative role of the spiritual forces in ensuring justice, equity and fair play in Igboland. Igbo names such as Onyemaechi (no one knows tomorrow), Maduabuchukwu (no one is like God) and Chizaram (God answered me) point to the spiritual realm influencing positively the physical existence of the Igbo.

\section{Problems and Prospects of Atheism and Humanism}

Human salvation is not made possible to atheists. This is because they have created and sustained or preserved the gulf between the Creator and man since creation of the universe does not accept man's salvation. Similarly, the cosmic chaos which has characterized every creation story could not be resolved by human efforts and the cosmic forces were brought to order and divine control by God. This made the light to prevail over the power of darkness, chaos, anarchy and confusion.

MacGregor is of the view that "even in heaven, where man's individuality is perfectly and fully developed, man never becomes God. That man should become 'as God' was satan's deceitful promise, a means of tempting man to indulge in delusions of self-grandeur that would be his undoing, leading him to misery and ruin" (p. 88).

The strength of the above argument shows that atheism is weakened by the reality of the elaborate provisions hitherto expressed to the fullest extent both the remoteness and inaccessibility of God, on the one hand, and on the other, His intimate nearness and abiding presence. The religious feelings associated with Igbo traditional religion is presented in its most startling, provocative and dramatic form.

It is easier to reach an honest conclusion that a supreme mind is in benevolent control of the universe than to conclude there is no God. Similarly, wherever you find evidence of disorder and lack of purpose, you find evidence against God, or the strong feeling remains that we must not forget, how deeply ingrained are our habits of self-deception, especially in matters that involves important choices.

Careful observation of Igbo world views shows that we are confronted with human experience that is apparently baffling. Consequent upon this predicament, some subscribe to atheism and think no more of the matter. Atheists have been sorely described and criticized over the centuries in varying terms because they did not believe that nothing is good except God. Camus (1961) came up with "the absurd man". "The absurd man lives outside God and therefore prefers his courage and his reasoning. The first teaches him to live without appeal and gets along with what he has; the second informs him of his limits ...” In preference to God he chooses an absorbing passion ... as man he is his own end ... whatever comes to him or upon him he accepts as fate without grumbling for a fate is not a punishment ... To him, nothing is vanity except the hope of another life for "what comes after death is futile; ... Therefore, between history and the eternal, he chooses history because he likes certainties ... his mind is made up that he will live out his adventure within the span of his life time ... 'The wise man ... lives on what he has without speculating on what he has not'. He has no concern with ideas or with the eternal. The truths that came within his scope can be touched with the hand-he cannot separate from them ... It is 'royal power' to 'know how to live in harmony with a universe without future and without weakness', to think clearly and cease to hope". Thus, "the absurd man" refuses to take a leap, "rushing into the divine or the eternal”, or to afford himself of any screens which may hide the 
true facts of life from him (p. 49).

Idowu (1978) observes that those who are represented in 'the absurd man', religion, and God have no existential or pragmatic meaning; no useful, desirable purpose. The universe with its challenges such as the problem of evil exemplified in death at the prime of life, accidents, volcanic and epidemic outbreak with disastrous consequences make man helpless. Man is after all disposed to try to find order whether it is there or not. Man is endowed with remarkable abilities for doing so, cannot but admits that on all sides there is ample testimony to aimlessness, futility, waste and chance. Scholars have concluded that the universe is purposeless and therefore in itself meaningless.

Atheism remains one of those inappropriate labels used in describing religious belief system and which has posed a fresh challenge to scholars of Igbo culture. It has called for an inward collaborative study in order to distinguish classical or original meaning from the realities of the day. Igbo cultural scholarship will remain on the defensive if the biased conclusion of scholars even of African identity is not addressed.

Momoh (1996) avers that "originally Africans had no conception of God, the Supreme Being, in the Judeo-Christian senses of the world but that point by itself should not be construed to mean that Africans were thereby immoral ... it cannot be automatically assumed that a religious man is a moral man, or that a moral man is a religious person. Even though Africans, before the advent of Christianity, and Islam, had no conception of the Supreme Being. God, they had and still have conception of gods whose moral predicates are similar to those of the monotheistic God” (p. 20). The monotheistic God in Igboland is higher and above Momoh's identified "gods". Chineke, Nyame, Olorun, Olodumare and other monotheistic conceptions of the Supreme Being in Africa were in place and referred before the advent of Christianity and Islam. These two religions, in fact borrowed these names of God and their attributes. They are not mere philosophical speculations but are real, unique and impart lives practically in daily living. Any contrary view implies blindness to the cultural realities on the group.

Shading mere light on the deserved realities of intellectual cross-fertilization, in Igbo culture, it is the labels mere applied to Igbo cultural life not because they were meant for concentration or revere empty objects but because they believed that behind every being or object, there is a vital force, power or spirit. Dukor (2010) clarifies some of the Igbo religious issues when he asserts that "Africans personify nature because they believe that there is a spiritual force residing in every object of nature. African religious practices, feasts and ceremonies cannot precisely be equated to magical and idolatory practices or fetishism" (p. 88).

The Supreme Being is identified with the universe in Igbo culture. Dukor (2010) maintains that the possible common cultural heritage of the Africans of which the Igbo are one, therefore their belief in the multiplicity of divinities as messengers of God, means to an end and ministers of God were either created or governed by an ultimate being or principle or they were part of it. It is for this reason that it is possible that African culture in general and the Igbo culture in particular may not be atheistic as some people think. It is theistic as well as humanistic. The relationship between atheism and humanism could be seen in denial of the existence of God, gods and spirits on one hand and none inclusion, recognition and incorporation of God or religious sentiments.

Dukor (2010) formulated the principle of doctrine of Theistic
Humanism as possible Afro-Asian common cultural heritage. In African ethics, an action is not bad because God said it is not bad and good because He said it is good. Things are good or bad independent of the will of God. In the realm of spiritualism, both cultures are also humanistic. Uche (2007) sees divinities, spirits and ancestors in Africa as guardians of morality. They were ever-ready to ensure the continued existence of society. Igbo attitude to life is through diligence provided it does not jeopardize one's life. The intellectual and spiritual self-control of man are extolled.

Atheism has brought to lime-light the quest to establish philosophical import of religious world-view, myths and symbols in Igbo culture as well as their meaning and cultural relevance to the intellectual emancipation of Igbo culture from Eurocentric intellectual traditional. Similarly, it is believed that metaphysical knowledge statements and problems are both characterized by the misuse of language. This misuse of language could be broken if scholars accept myths, folklore, proverbs and religious beliefs as sources of Igbo philosophy show casing Igbo traditional knowledge to the globalized world.

Humanism seems to virtually identify with all people by influencing them with their ideas, views, attitudes and teaching. They have a long time effects on people, institutions and relationships. Touching on lives could be positive as well as negation in a generation which Okoye (2006) sees as increasingly secular and freedom seeking in which authority figures is seen as misnomers and enemies to human aspirations.

Any genuine humanist is supposed to be working for the welfare of the human person as in his true nature (that is as a being with dignity and autonomy-a person). Many humanists tended to over exaggerate human capacity and ended up giving man such centrality that placed him in the protagoran sense as "the measure of all things". This encouraged the anti-religious perception of humanism among many people in history.

Humanism assigns to the human person an absolute, inviolable, non-instrumental value, worthy of the greatest respect and consideration. Mondin (1985: p. 257) avers that "it is evident that man is not an absolute, not a Supreme Being, nor is he omnipotent, infinite, or immortal” (p. 257). Humanism embraces more properly any attitude that exalted man's relationship with God, his free will and his superiority over nature. Humanism makes man the measure of all things. Humanism regards human reason as the best guide in facing life's problems; humanists want to see society from the stranglehold of religious beliefs. Humanists are free thinkers because they never hand over their minds irrevocably to any church, but remain free to think for themselves.

Humanism explains that every responsible human being should be free to make choices and live in their own life style, as long as they do not violate the freedom of others. The humanists' virtues are a regard for what is true, personal responsibility, tolerance, consideration, breath of sympathy, public spirit co-operative endeavour, and concern for the future. Humanists although not religious, will arguably live beside the religious, believing in freedom for religion and freedom from religion. Its emphasis is on the human, here-and-now, its not a religion and it has no formal creed, yet, humanists have belief.

Humanists are atheists or agnostics and do not expect an after life. It is essential to humanism that it brings values and meaning into life. But these virtues and values are expressed in Igbo culture. God centred philosophical value and virtues such as kindness, love, patience, humility, diligence and honesty will 
meet human aspirations in the globalized world if they are anchored on God which is of prime value. Man is limited in knowledge, power and spirit and would need a divine spark, essence and link to remains focused and less distracted by the desires of the flesh.

Christian humanists such as William Wilberforce and John Macpherson made a strong case against slave trade in British Parliament. They appeal to the conscience and true humanity of fellow Britons to think less of the profit they made from the trade on human beings. Promoting equality of human beings was practically demonstrated. In this way, humanism remains a radical breakthrough into economics for the liberation of man, a scientific revolution against forced labour of the economic industrial countries over the poor African nations including Igbo extraction. Humanism holds that culture as a way of life exists in all the communities. It allows for dignity and self-esteem that is fundamental to cultural development. Cultural development therefore, implies learning and education as aspect of culture being promoted by humanism.

In a related level, he sees humanism as any system which puts human interest paramount. Dukor sees African culture as an example of a culture that is humanistic while at the same time holding the belief in transcendental beings like spirits, gods and so on. It is shown by this idea that though Humanism and Theism appear as contraries yet both can be true in African and Asian cultures. They are existentially pragmatic in their philosophies which are a medley of pantheism, polytheism and theism. Also, polytheism, theism and pantheism are features of African civilization. African civilization is preoccupied with not only the interest and welfare of man, but also with spiritualism. Here spiritualism is for man and not man for spiritualism. This is the basis of agrarian and egalitarian cultures in Africa in general and Igbo land in particular. There is a common belief in the plurality of divinities. Most of these divinities have specific functions in their relationship with man. For example, Ilo Uwa is associated with reincarnation in Igboland. It is interesting to note that in Igbo mythologies, the chi which is interpreted "the lesser gods” Dukor (2010) were either created by God or they were part of Him. In Igbo Religion, God, called Chineke (creator) is the Supreme Being, God is conceived as a Transcendental and Immanent Being. The lesser beings were created by Him or emanated from Him. They are symbols of Divine reality, source of African Traditional Religious Ethics. The worship and sacrifices to God were not useless. Where deification occurs, the followers recognize and raise the status of the deity from ordinary to divine level.

Humanism could be only in a very lopsided and unscientific philosophical manner since it says nothing of the very innate nature of man, rather, devilled only on the peripheral area that can be covered by even political science or civil education or other. Humanism presents the posture of misguided as a protestation against religion, transcendental realities and ontology. This explains why many humanists are viewed always as atheistic, or atheistic, or agnostic, secular or apostheosistic (equating man with God).

Ignorance is a factor responsible for the error of judgment expressed concerning African world view. The African philosophy of life according to Dukor (2010) states that "the world is inhered with ultimate invisible spiritual powers which is both a form of matter and motion as could be seen in Marxian and Einsteinian conceptions of matter, motion and space times. It is therefore wrong to argue that the African people culturally lack the scientific spirit” (p. 62). There is substance in holding that the sweeping confusion could have been averted if we appreciate that the form and sophistication may not be the same level with that of the west.

It involves human effort to recover something in human life connected to having kindness, sympathy and being benevolent. Its emphasis is on human interests rather than on religion. But how far could human interest go in a world of greed, corruption and wickedness. In its pure form, humanism is anti-religion and is regarded as "pagan”. It is a kind of revolt against Christian religion. Humanists are caricatured as dry rationalists worshipping pure reason. But its unreasonable to extend the use of reason to all areas.

It would be impossible for humanists to force humanisms other people or to persecute non-humanists for if they do, they will no longer be humanists. Humanists see no virtue in faith, blind obedience, meekness, unworldliness, chastity, or pointless self denial. They do not believe in miracles, though, they can ironically comprehend the senses of the miraculous.

\section{Implications of Atheism and Humanism in a Globalized Igbo World}

In addition to the problems and prospects of atheism and humanism analyzed above, a critical look at their implications in a globalized Igbo world will help champion the way forward. Igbo is the Jew of Nigeria and by implication the cradle of mankind and civilization. Therefore, the Igbo cultural decay, under development and downfall to the evolutionary ladder must have been due to the accidents of history caused by radical conflicts and the survival of the fittest. It is the contention of this paper that the Igbo experience in the globalized world must not only discard a dead culture but must also embrace those of our past for posterity, those of her primeval or pristine culture which was responsible for the early development in science and technology. In order to exploit the Igbo universe which is a dynamic, progressive and purposeful for the development in every sphere of operations, Dukor (2010) suggests “Theistic humanism which is African philosophy of God, man and universe as well as African personality and self could invent, discover, cognize, construct and deconstruct” (pp. 62-63). This position seems to explore the relevance of African philosophy of God which is deeply rooted in Igbo culture in particular and African culture in general. A deep rooted search for Igbo identity is a synergy for collaborative partnership for sustainable development.

There is need to establish a case of Theistic humanism against thread bare humanism; a critique of humanism in defence of Igbo and African Theistic humanistic cultures. Humanistic tendencies are not lacking in traditional and modern Igbo thought because man is the core of Igbo thought. Man is the beginning and end in expressing God's thought.

The Igbo attitude is that theism or conception of God is a necessary denomination in all human affairs. Igbo cosmology and ontology are world affirming with men at the centre of the cosmos in Igboland. God created man in his image and put his breath for substance, growth and development. Dukor (2010) avers that in African philosophy, we find that in a particular sense, these philosophies are humanistic but their humanism is combined with theism. Ignoring this fact does not promote the richness in Igbo world views in a globalized world.

One of such riches is embedded in Igbo proverbs. Proverbs 
express exoteric knowledge of the mysteries of Igbo culture. The wisdom manifested in Igbo proverbs needs deep insight before a meaningful understanding could be made. Myths and folklores are not left out. Scholars researching on them ought to be versed in Igbo language and philosophy in order not to read in and read out of the realities of these traditional forms of philosophical expositions. The above riches are made possible with the divine manifestation empowering and sustaining Igbo proverbs, myths and folklore as sources of Igbo traditional ethics and religion.

Similarly, Igbo names mentioned earlier in this paper have no place in atheism and humanism except perhaps for the divine of spiritual force inherent in them. The prefix chi is noticeable in most Igbo names. Chi implies God or spirit and therefore God centred. The belief that God or religious beliefs and practices have no influence on or connection with the running of a country has no bearing in the globalized Igbo world.

Igbo communalism is celebrated for a number of reasons. Unity is strength and the spiritual forces are brought in to solidify this communalism. Uche (2007) avers that Ofor holders in conjunction with medicine men and other religious functionaries bring their spiritual experience to bear on the spiritual life in a globalized Igbo world. The promotion of Igbo land is said to lie in our hands. Efforts are complimented by a set of taboos which produce a repulsive effect on rebellious prone Igbo.

Divination according to Ukaegbu (2005) is a practice of diligently inquiring into a matter through inquisitorial and consultation. The troubled will seek for a clue by enquiring or consulting the diviner. The Igbo adaptation of inquisitorial system enables the adaptation of the earth and the heaven ecologically. Curses and religious symbols compliment the enforcement of the spiritual force that brings about spiritualism which notifies atheism and weakens humanism.

Another dimension to promoting unity in Igbo land is through presentation and eating of kola. Kola serves a divine purpose. Ukaegbu (2005) traces the origin of kola to our forefathers whom God revealed kola in order to bring men together. Whenever it is presented, men must be thankful to God. The symbolic purpose of being used to unity love, trust and good relations among brothers. Kola glues together other aspects of Igbo customs such as marriage, festivals, and burials. Kola is heart-like and it is blessed through prayer before it is eaten. Kola reveals what is in the heart. The purpose of the kola nut is said to be reconciling and uniting people in a covenant of trust. Other qualities of kola include a Supreme role of securing people's trust to deal freely with one another, strengthen faith, create awareness, secure commitment to custom and strengthen trust.

The Igbo are known for hardwork. Ikenga in Igbo philosophy remains the Igbo symbol for hard work. Ekwuru (2009) sees ikenga as the epitome of existence which symbolizes a force in motion; reflect the status of a man and a status symbol. Ikenga as a symbol for hard work is realizable only within the spiritual enforcement. Ikechukwu as the Igbo personal name which explains that it is by God's power one has achieved great things, success and progress in life. This explains the reason for diligence, patience and commitment. Uche (2009) identifies filial bond and devotion as the basis for development. In a related development, Uche (2010) sees filial piety which is undying devotion to duty as a synergy for national development in a globalized economy. These two references are relevant in explaining God as the hub upon which the waves of change, pro- gress and development are established.

The transformation brought about by the ingenuity and creativity of the Igbo weakens the undue attention placed on the role of science and technology in improving the lot of man in a globalized world. An idle mind is the devil's workshop. Man's inhumanity to man, avarice and corruption seem to be on the increase despite technological advancement. The spirit of God in the life after has turned many away from wickedness and unrighteousness.

\section{The Way Forward}

Theistic humanism is recommended as a metaphysical principle deduced from the African world of divinities, ancestors and spirits. Igbo religion promotes spirituality which permeates every facet of human existence in Igbo world. Virtually, Igbo religion from its rites and rituals to its ethical detects, it presented as something that can protect his prosperity and good fortune, bring rain, heal the sick and in general ensure good fortune in Igbo in particular and Africa in general. In Igboland, most diviners are believed to possess esoteric power and knowledge. These make them under possession of spirits or supernatural powers when engaged in divination, and doctors claim that they are chosen by spirits, taught medicine by spirits and guided in their profession of diagnosis and healing divine power.

They have set taboos as ethics of profession which constrain them spiritually to refrain from doing things that are inimical to man. Any violation of these taboos brings about divine sanction and punishment. In the Igbo world of divinities, spirits and ancestors, there is the metaphysical instrument of checking and punishing moral or civil or criminal offences. In Igbo culture, the spiritual order visits retribution to those who were greedy, corrupt and wicked in indulging in abominable acts, actions, attitudes and behaviours.

Theistic humanism underlines Igbo egalitarian, fair-play and justice. Hence, Isa-Aka, Iju ogu remain instrumental to social justice in Igboland. Dukor (2010) says "theistic Humanism is, therefore, the philosophy, in the belief in God, gods, spirits, ancestors, objects, myths, symbols and of the interest of man" (p. 103). These philosophical objects play functional and vital roles as scientific objects and variables. Man as a philosophical subject exercises authority, control and function over philosophical objects.

\section{Conclusion}

Examining the notions about God which are prevalent across the world made it possible to consider or understand whether these notions match the stature and nature of the Divine Being they wish to commit their lives. The cumulative force of divergent views especially the misconceptions of these concepts arose out of ignorance, confusion and mischief aimed at misleading people in reading in and out of what is not in place. The intensity of global times called for a systematic review of atheism and humanism as they impinge on Igbo experience. This has become necessary in order not to resist the wind of change cutting across the globe. A balanced understanding of Igbo experience of atheism in a globalized world indicates that the concept does not hold. The Igbo do not query the existence of God. Whatever predicament man faces is consequent upon man's acts of rebellion and disobedience to divine instructions. 
In the face of the identified challenges, this paper joins hand with Dukor $(2007,2010)$ in making a strong case for and advocating theistic humanism. Theistic humanism holds that "cultural values have transcendental and theistic origin" (p. 3). It is observed therefore, that the Igbo belief system, religious structure, personal names, religious symbols and religious values make the Igbo to think, sing and dance religiously. There is no aspect of Igbo life God is not central. Chineke (Creator) is the hub of Igbo world view. He is different from the divinities recognized as God's messengers, ministers and the link between God and man. The ancestors occupy the spiritual realm with God. This clarified view makes for mutual respect and socio-religious development in a globalized Igbo world.

In its pure form, atheism and humanism are anti-religion. As a product of renaissance, they have revolted against Christian religion which was characterized according to Uche (2007) by poverty, injustice and remained stumbling blocks to reform. The church not only led to state bankruptcy but also to economic depression of the masses. They were products of radical opposition to too much of intellectualism of scholastic theology and philosophy. They concerned themselves with the importance of man, his affairs, temporal aspirations and well being. Christian humanists consider man as a being that has no meaning without his ontological anchor with God. Thus, man's unity, dignity and equality of all men are temporal outside God. There is a substance in holding that man is a being with a purpose. To the Igbo, atheism and humanism do not provide adequate bond of cooperative citizenship in a globalized Igbo world.

\section{REFERENCES}

Abbaganno, N. (1967). Humanism. In P. Edward (Ed.), The encyclopedia of philosophy (Vol. 4). New York: Macmillan and Free Press.

Camus, A. (1961). The myth of sisyphus. New York: Vintage books.

Chukwujekwu, S. C. (2007). Personalism and humanism in the philosophy of Pope John Paul II. Annual memorial lecture series. Awka: Charles and Patrick.

Doniger, W. (1999). Merriam-Webster's encyclopedia of world religions. Massacusetts.

Dukor, M. (2007). Propositions of African cultural values. Journal of the society for Arts and Humanities, 2, 1-6.

Dukor, M. (2010). Theistic humanism of African philosophy: A great debate on substance and method of philosophy. Berlin: Lambert Academic Publishing.

Edwards, F. (1989). What is humanism. Washington: Executive Director American Humanist Association.

Ejizu, C. I. (1986). Continuity and discontinuity for Igbo traditional religion. In E. I. Metuh (Ed.), The Gods in retreat. Enugu: Fourth Dimension.

Ekwuru, E. G. (2009). Igbo cosmology: The ontogeny and hermeneutics of Igbo sculture studies in african ethnoaesthetics. Owerri: Living Flames Resources.

Epstein, C. M. (2010). Good without God: What a billion nonreligious people do believe. New York: Harper Collins.

Haralambos, M., Holborn, M., \& Heald, R. (2008). Sociology: Themes and perspective. London: Collins.

Kalu, O. U. (1978). Precarious vision: The African perception of this world. Enugu: Fourth Dimension.

Madu, J. E. (2003). The paradox of the "one" and the "many" in religion. Niger: Global communications.

Madu, J. E. (2004). Honest to African cultural heritage. Onitsha: Coskan Associates.

MacGregor, G. (N.D). Introduction to religious philosophy. London: Macmillan.

Mairi, R. (1998). Chambers 21st century dictionary. New Delhi: Allied
Chambers.

Metuh, E. I. (1978). Comparative studies of African traditional religion. Onitsha: Imico.

Nwala, T. U. (1985). Igbo Philosophy. Ikeja: Literamed.

Ugwu, C. O. T., \& Ugwueye, L. E. (2004). African traditional religion: A prolegomenon. Lagos: Merit international.

Momoh, C. S. (1996). African moral atheism. Essence: An International Journal of Philosophy, 1, 20-28.

Mondin, B. (1995). Philosophical anthropology. Rome: Urbaniana University.

Onunwa, U. (1990). Studies in Igbo traditional religion. Obosi: Pacific.

Richard, O. (1983). A critique of revolutionary humanism. Frantz Fanon, Missouri: Warren H. Inc.

Ogunmodede, F. (2007). John Paul II and the problem of humanism. In S. C. Chukwujekwu (Ed.), Personalism and humanism in the philosophy of Pope John Paul II Annual memorial lecture series. Awka: Rex Charles and Patrick.

Okeke, D. C. (2002). Foundations of religious studies. Enugu: Rabboni.

Okoye, J. I. (2007). Keynote address: Personalism and Humanism in the philosophy of Pope John Paul II. In S. C. Chukwujekwu (Ed.), Personalism and humanism in the philosophy of Pope John Paul II Annual memorial lecture series. Awka: Rex Charles and Patrick.

Ritzer, G. (2012). Sociological theory. New York: McGraw-Hill.

Stumpf, S. E. (1975). Philosophy: History and problems. New York: McGraw-Hill Book Company.

Umezinwa, C. (2009). Why we study humanities. In I. Emejulu, \& C. Umezinwa (Ed.), Humanities for tertiary institutions. Ogidi: MasterPrint.

Ukaegbu, F. N. (2002). The Igbos: The Afrikan root of nations. Ibadan: Hernemann, Educational Books.

Uche, O. O. C. (2006). The dynamics of religion as a matrix of culture. In N. Ojiakor, \& Iyke (Eds.), Readings in Nigeria peoples and culture. Enugu: NGIB Publishers.

Uche, O. O. C. (2007a). Comte's religion of humanity: Some sociological implications. Journal of the society for Arts and Humanities, 2, 18-26.

Uche, O. O. C. (2007b). Globalizing African priesthood essence. International Journal of Philosophy, 4, 91-101.

Uche, O. O. C. (2007c). Preservation of African cultural values in the 21st Century. In N. Ojiakor (Ed.), Salient issues in Nigerian history, culture and socio political development. Enugu: Emmy Angel Publishers.

Uche, O. O. C. (2009a). Basic belief system in African traditional religion. In F. Aghamelu, \& C. Asomugha (Eds.), Readings in African thought and culture. Enugu: Strong Tower.

Uche, O. O. C. (2009b). Shinto and industrial development in Japan: Lessons for Nigeria. In I. Emejuru, \& C. Umezinwa (Eds.), Humanities for tertiary institutions. Aforigwe Ogidi: MasterPRINT.

Uche, O. O. C (2009c). The socio-religious significance of taboos in Nigeria. In F. Aghamelu, \& C. Asomugha (Eds.), Readings in African thought and culture. Enugu: Strong Tower.

Uche, O. O. C. (2010). Filial piety: A religious synergy for national development in a globalized economy. In A. B. C. Chiegboka, T. C. Utoh-Ezeajugh, \& G. I. Udechukwu (Eds.), The humanities and globalization in the 3rd millennium (pp. 292-298). Nimo: Rex Charles and Patrick Ltd.

Uche, O. O. C., \& Grace, A. O. (2010). Divinities and social integration in Africa. Journal of the Society for Arts and Humanities, 5, 122-129.

Uche, O. O. C. (2011a). Obnoxious labels as a language of class struggle in Nigeria; the Igbo experience: African research review. An International Multi-Disciplinary Journal, 5, 197-211.

Uche, O. O. C. (2011b). Religion and sustainable development in Nigeria; a functionalist prospective. In A. B. C. Chiegbuka, T. C. Utoh Ezeajuah, \& M. S. Ogene (Eds.), The humanities and sustainable development (pp. 350-359). Nimo: Rex Charles and Patrick.

Uchendu, V. C. (1965). The Igbo of south-eastern Nigeria. Chicago: Holt Reinhart and Winston. 